\title{
NOVÝ TREND: OMEZOVÁNÍ A VYLUČOVÁNÍ PŮSOBNOSTI ORGÁNU゚ OCHRANY PŘÍRODY PRO ÚČELY POVOLOVÁNÍ STAVEBNÍCH ZÁMĚRU゚*
}

\author{
VOJTĚCH STEJSKAL
}

\begin{abstract}
New Trend: Limitation and Exclusion of Powers and Scope of Natural Protection Authorities for the Purpose of Permitting of Building Projects

The paper deals with legislative changes related to the process of permitting various building projects. Their goal in the present legislation as well as in the upcoming legislation is to simplify and speed up proceedings of permitting building projects. The author focuses on the legislation parts that affect the scope and powers of environmental protection authorities, especially the nature conservation authorities. The aim of the paper is to point out the controversial laws and the laws that are being prepared with regard to the scope of authorities in the field of nature protection for the building permit process and to carry out their critical analysis.
\end{abstract}

Keywords: nature conservation authorities; opinion; binding opinion; building project; building act; public interest

Klíčová slova: orgány ochrany př́rody; stanovisko; závazné stanovisko; stavební záměr; stavební zákon; veřejný zájem

DOI: $10.14712 / 23366478.2019 .24$

\section{1. ÚVODEM}

V posledních letech se setkáváme v rámci legislativních změn souvisejících s procesem povolování různých stavebních záměrů s požadavky (většinou) ministerstva pro místní rozvoj, ale i ministerstva dopravy na úpravu působnosti a pravomoci orgánů ochrany životního prostředí, s cílem zjednodušit a zrychlit řízení ve věcech povolování bodových, ale i liniových staveb. Je zvláštní, že mezi orgány ochrany životního prostředí je cílem těchto změn zejména zákon č. 114/1992 Sb., o ochraně přírody a krajiny. V podstatě tyto změny cílí jenom na orgány ochrany prŕrody. Působnost a pravomoc ostatních orgánů podle jiných speciálních zákonů, zůstávají naopak většinou beze změny, např. vodoprávní úrudy či orgány památkové péče. Zda to svědčí o politické slabosti

* Tento př́spěvek byl zpracován za podpory výzkumného programu Univerzity Karlovy Q 02 Publicizace práva v evropském a mezinárodním srovnání. Autor si dovoluje poděkovat za připomínky třem anonymním recenzentům. 
př́islušného resortního ministra, resp. síle příslušného resortního ministerstva, netroufám si spekulovat. Cílem mého př́ispěvku je naopak zaměřit se na legislativní otázky, na zásadní provedené či připravované změny v oblasti působnosti orgánů ochrany př́rody pro účely povolování stavebních záměrů, a to z pohledu právního. V první části se budu zabývat již provedenými legislativními změnami, konkrétně zákonem č. 225/2017 Sb., $\mathrm{v}$ druhé části navrhovanými paragrafovanými změnami v souvislosti s novelizací zákona č. 416/2009 Sb., v třetí části navrhovanými paragrafovanými změnami v souvislosti S novelizací zákona č. 183/2006 Sb. a zákona č. 254/2001 Sb., a ve čtvrté části navrženým věcným záměrem nového stavebního zákona.

\section{2. ÚVAHY NAD ZMĚNOU ZÁKONA O OCHRANĚ PŘÍRODY A KRAJINY PROVEDENOU ZÁKONEM Č. 225/2017 SB.}

Zákon č.225/2017 Sb. přinesl pro rozhodování orgánů ochrany prŕírody několik podstatných změn. Za prvé, zavedl $\S 8$ odst. 6 , podle kterého ke kácení dřevin ,pro účely stavebního záměru povolovaného v územním ř́zení, v územním řizení s posouzením vlivư na životní prostředi, ve společném územním a stavebním řizení nebo společném územním a stavebním řizení s posouzením vlivů na životni prostředi je nezbytné závazné stanovisko orgánu ochrany přrirody. Toto závazné stanovisko vydává orgán ochrany př́rody př́slušný k povolení kácení dřevin. Povolení kácení dřevin, včetně uložení přiměrené náhradní výsadby, je-li v závazném stanovisku orgánu ochrany přrirody stanovena, vydává stavebni úr̆ad a je součástí výrokové části rozhodnutí v územním ř́zení, v územním řizení s posouzením vlivů na životní prostředí, ve společném územním a stavebním řizení nebo společném územním a stavebním řizení s posouzením vlivi̊ na životní prostředi." Zákon č. 225/2017 Sb. tedy mění dosavadní způsob povolování kácení dřevin rostoucích mimo les pro účely stavební činnosti podle stavebního zákona, nebot' $\mathrm{v}$ tomto př́padě toto povolení vydává namísto orgánů ochrany př́rody nově stavební úrad jako součást výrokové části územního, popř. jiného rozhodnutí dle stavebního zákona (vypočtené v textu $\S 8$ odst. 6 zákona o ochraně prírody a krajiny) na základě závazného stanoviska orgánu ochrany př́rody a krajiny.

Nová právní úprava zavádí institut závazného stanoviska orgánu ochrany př́rody, které se vydává pro účely řízení podle stavebního zákona a na jeho základě stavební úřad ve výrokové části rozhodnutí rozhodne o povolení (či nepovolení) kácení dřevin rostoucích mimo les, popř. též bude moci postupovat podle $\S 9$ odst. 1 zákona č. 114/1992 Sb. ${ }^{1}$ Výhodou tohoto řešení je z časového hlediska primární řešení otázky kácení dřevin orgánem ochrany př́rody, zároveň však s možnými účinky a tedy vykonavatelností až okamžikem právní moci územního rozhodnutí (popř. společného povolení). Nemůže tedy nastat situace, kdy povolení bude vydáno a bude možno dřeviny vykácet, ačkoli žádost o vydání územního rozhodnutí bude zamítnuta. Zároveň však stavební úrúad bude rozhodovat v situaci, kdy se orgán ochrany přírody již věcně otázkou kácení zabýval a udělil ke kácení kladné stanovisko (záporné stanovisko pochopitelně

1 K $\S 8$ a 9 viz např. VOMÁČKA, V. a kol. Zákon o ochraně př́rody a krajiny. Komentář. Praha: C. H. Beck, 2018. 
znemožňuje stavebnímu úřadu žádosti o územní rozhodnutí vyhovět). $Z$ výše uvedených důvodů odborná literatura tuto novou právní úpravu připodobňuje k právní úpravě odnětí půdy ze zemědělského půdního fondu. ${ }^{2}$ Osobně však tuto změnu $\S 8$ odst. 6 zák. č. 114/1992 Sb., ve znění zákona č. 225/2017 Sb. považuji za problematickou, nebot' po 26 letech kontinuálního rozhodování podle zákona č. 114/1992 Sb. se odebírá orgánům ochrany prrírody věcná působnost rozhodovat o kácení dřevin rozhodnutím.

Mnohem problematičtější př́ípad ovšem představuje novelizace $\S 56$ zák. č. 114/1992 Sb., o ochraně přírody a krajiny, provedená rovněž zákonem č. 225/2017 Sb. Připomeňme, že se jedná o rozšíření dosavadních forem vydávání výjimek ze základních ochranných podmínek zvláště chráněných druhů. Ke změně nebyl jediný racionální důvod, ř́zení fungovalo v zákoně č. 114/1992 Sb. bez problémů od roku 1992. Oproti změně $\S 8$ odst. 6 je třeba zdůraznit, že změnu $\S 56$ nenavrhlo ani ministerstvo životního prostředí, ani vláda, jednalo se o účelový poslanecký pozměňovací návrh podaný ve druhém čtení.

Podle $\$ 56$ odst. 6 zák. č. 114/1992 Sb., ve znění zák. č. 225/2017 Sb., ,zjistí-li se až po zahájeni územniho ř́zeni, územniho ř́zeni s posouzením vlivư na životni prostředí, společného územního a stavebního řzzení, společného územního a stavebního řizení s posouzením vlivů na životni prostředí nebo stavebniho ř̉zení, že stavebním záměrem povolovaným v tomto řizení budou dotčeny ochranné podmínky zvláště chráněného druhu rostliny nebo živočicha stanovené $v \S 49$ nebo 50, a tato skutečnost nebyla pred zahájením tohoto ř́zeni známa, lze rozhodnutí v tomto řizení vydat pouze na základě závazného stanoviska orgánu ochrany př́rody přislušného k povoleni výjimky ze zákazů u zvláště chráněných druhů rostlin a živočichů, v němž orgán ochrany prírody posoudí splnění podmínek pro povolení výjimky uvedených $v$ odstavcích 1 a 2 a může stanovit prípadné dalši podminky povolení výjimky podle odstavce 3. Povolení výjimky ze zákazů u zvláště chráněných druhů rostlin a živočichì včetně stanovení dalšich podminek podle odstavce 3 je součástí výrokové části rozhodnutí vydávaného v územním řizení, vúzemním řżení s posouzením vlivu na životni prostredí, ve společném územním a stavebním řizení, ve společném územním a stavebním řizení s posouzením vlivů na životní prostředí nebo ve stavebnim rízeni. “"

Stručně řečeno, povolování výjimky dle § 56 zákona č. 114/1992 Sb. ze zákonem zakázaných činností do 1. 1. 2018 bylo co do formy prováděno jen 1) rozhodnutím orgánu ochrany přírody, 2) opatřením obecné povahy a nebo 3) veřejnoprávní smlouvou, vše vedené v samostatném řízení př́islušného typu věcně a místně př́slušným orgánem ochrany př́rody. ${ }^{3}$ Tedy nikoliv závazným stanoviskem coby prostého podkladového aktu! Právní úprava je tedy v rozporu s legislativně ustáleným právním režimem povolování výjimek. ${ }^{4}$ Zde je třeba dále upozornit, že v př́padě $§ 56$ nejde o formu souhlasu k zákonem dovoleným činnostem, jako je tomu v jiných ustanoveních zákona

2 FRANKOVÁ, M. Změny v právní úpravě ochrany př́írody při umistování staveb a změnách využití území. České právo životního prostředí, 2017, č. 3 (45), s. 56-79.

3 K formám vydávání výjimek dle § 56 viz STEJSKAL, V. Komentár k zákonu o ochraně prírody a krajiny. Praha: Wolters Kluwer, 2016 nebo VOMÁČKA, V. a kol. Zákon o ochraně prírody a krajiny. Komentár. Praha: C. H. Beck, 2018.

4 Shodně např. FRANKOVÁ, M. Změny v právní úpravě ochrany př́rody při umistování staveb a změnách využití území. České právo životního prostředí, 2017, č. 3 (45), s. 56-79. 
č. 114/1992 Sb., např. v § 44 odst. 3 (bližší ochranné podmínky zvláště chráněných území), nýbrž že se jedná o výjimky ze zákonem zakázaných činností. O těchto musí rozhodovat orgán ochrany př́rody, a nikoliv stavební úřad.

Proto je třeba odmítnout konstrukci, jakou zavedl v $§ 56$ odst. 6 a 7 zákona o ochraně př́rody a krajiny zmíněný zákon č. 225/2017 Sb., jako nepríijatelnou. Vedení správního řízení a vydání finálního rozhodnutí o povolení výjimky formálně totiž přísluší nově od 1. 1. 2018 stavebnímu úřadu, tedy orgánu veřejné správy, který vůbec není věcně a místně př́íslušný k posuzování zájmů ochrany př́rody a krajiny, a to ani podle zákona č. 114/1992 Sb., o ochraně přírody a krajiny, ani podle stavebního zákona. Navíc je třeba zdůraznit, že stavební úřad není orgánem ochrany př́rody podle $§ 75$ zákona č. 114/1992 Sb. Dalším argumentem proti nové úpravě je, že žádný konkrétní orgán ochrany prrírody nemá $\mathrm{v}$ zákoně č. 114/1992 Sb. založenou věcnou a místní prríslušnost vydávat výjimky dle $\S 56$ formou závazného stanoviska. Kromě toho jsem přesvědčen, že alespoň ve stávajícím systému není žádný stavební úrad schopen o tak odborné záležitosti, jako je druhová ochrana, odborně rozhodnout.

V príípadě udělení výjimky dle $\$ 56$ odst. 6 zákona č. 114/1992 Sb., ve znění zákona č. 225/2017 Sb., s účinností od 1. 1. 2018, stavební úřad formou závazného stanoviska bude de iure rozhodovat o zakázaném záměru, nebot' k povolení výjimky může dojít až na základě rozhodnutí stavebního úřadu, jehož součástí musí být jak výrok o povolení, resp. umístění záměru, tak výrok o povolení výjimky a podmínkách této výjimky na základě závazného stanoviska orgánu ochrany př́rody. Právní účinky závazného stanoviska o povolení výjimky nastanou až právní mocí rozhodnutí stavebního úrúadu. Skutkový a právní stav ke dni vydání správního rozhodnutí je prìtom rozhodný nejen pro obsah tohoto rozhodnutí, ale i pro jeho následný správní i soudní př̌zkum. ${ }^{5}$

\section{3. ÚVAHY NAD NÁVRHEM NOVELY ZÁKONA O URYCHLENÍ VÝSTAVBY DOPRAVNÍ, VODNÍ A ENERGETICKÉ INFRASTRUKTURY A INFRASTRUKTURY ELEKTRONICKÝCH KOMUNIKACÍ}

V současné době připravuje Ministerstvo dopravy spolu s ministerstvem pro místní rozvoj novelu zákona č. 416/2009 Sb. Tento zákon upravuje postupy při přípravě, umistování a povolování staveb dopravní, vodní a energetické infrastruktury a infrastruktury elektronických komunikací, při získávání práv k pozemkưm a stavbám potřebných pro uskutečnění uvedených staveb a uvádění těchto staveb do užívání s cílem urychlit jejich majetkoprávní prrípravu, umistování, povolování a povolování jejich užívání, jakož i vydávání podmiňujících podkladových správních rozhodnutí, a urychlení následného soudního přezkumu všech správních rozhodnutí v souvislosti $\mathrm{s}$ těmito stavbami.

V posledních letech bylo přijato několik novelizací zákona č. 416/2009 Sb., které obsahovaly změny směřující k urychlení príípravy staveb dopravní, vodní a energetické

5 Vycházím i z názoru FRANKOVÁ, M. Změny v právní úpravě ochrany př́rody při umistování staveb a změnách využití území. České právo životního prostředí, 2017, č. 3 (45), s. 56-79. 
infrastruktury a infrastruktury elektronických komunikací. Současně došlo k poměrně zásadním změnám i v obecné právní úpravě, zejména přijetím zákona č. 225/2017 Sb., kterým byl novelizován především stavební zákon a jímž došlo $\mathrm{k}$ zavedení nových typů rrízení, v jejichž rámci jsou umíst’ovány a povolovány stavby. ${ }^{6}$

Podle důvodové zprávy k návrhu novely zákona „,návrh dále eliminuje množství závazných stanovisek, povolení a souhlasů, která jsou potřebná pro uskutečněni stavby v režimu zákona č. 416/2009 Sb. Pokud bylo u záměru provedeno posouzení vlivů na životni prostředí, je nadbytečné a neefektivní tento zámér znovu posuzovat a vydávat dalši závazná stanoviska, povolení či souhlasy podle zákona o ochraně př́rody a krajiny. Navrhuje se proto v prípadě, že bylo provedeno posouzení vlivů na životní prostředí, umožnit realizaci stavby $i$ bez těchto dalšich povolení či souhlasů, respektive nepodmiňovat vydání rozhodnutí podle stavebního zákona závaznými stanovisky podle zákona o ochraně prírody a krajiny."

$\mathrm{Z}$ důvodové zprávy (nejen z citovaného úryvku textu) vyplývá, že orgány ochrany prrírody údajně zdržují př́islušná řízení, tím, že vykonávají svoji působnost a pravomoc a hájí tak veřejný zájem na ochraně př́rody a krajiny, v souladu s $\S 58$ odst. 1 zák. č. 114/1992 Sb. Tuto navrhovanou novelu včetně odůvodnění považuji za účelovou a pro existenci působnosti orgánů ochrany př́rody za potenciálně nebezpečnou.

$\mathrm{S}$ navrhovanou změnou dle mého názoru nelze souhlasit minimálně z následujících důvodů:

Není pravda, že by proces posouzení vlivů na životní prostředí byl obsahově totožný (shodný/obdobný) s obsahem řízení podle zákona č. 114/1992 Sb., ve kterých orgány ochrany prírody (§ 75 zák. č. 114/1992 Sb.) vydávají souhlasy nebo povolení, nebo závazná stanoviska. Jsou rozdíly v předmětu, účelu, cílech, postupu při řízení, a v nástrojích (formách správní činnosti).

Posouzení vlivů na životní prostředí není povolovacím řízením, výsledkem je pouze odborné zhodnocení dopadů zamýšlených záměrů, jakožto podklad pro navazující ř́ízení, nikoliv autoritativní rozhodnutí o povolení (schválení) záměru (projektu). Má tedy obsahově odlišný charakter na rozdíl od řízení o povolení nebo souhlasu.

U řízení podle zák. č. 114/1992 Sb., která jsou zakončena povoleními nebo souhlasy, jakožto samostatnými rozhodnutími orgánů ochrany přírody, rozeznáváme dvě situace: a) povolování (vyjádření souhlasu) činností nezakázaných a b) činností zakázaných (v tomto případu relativně), tedy takových, kde lze povolit výjimku př́ípadně odchylné opatření. V této druhé situaci, činností ex lege zakázaných, je nemyslitelné, aby proces EIA rozhodoval o výjimkách ze zakázaných činností, $\mathrm{k}$ něčemu takovému není v zákoně č. 100/2001 Sb., (standardní EIA) ani v § 45h a § 45i zák. č. 114/1992 Sb. (naturová EIA) zákonný podklad (úprava).

Je nepřijatelné - a nelze to ani odborně a rozumně zdůvodnit - omezovat či vylučovat věcnou a územní působnost a pravomoci orgánů ochrany př́rody z důvodů, které

6 Na zákon č.225/2017 Sb. i na př́pravu novely zákona č. 416/2009 Sb. upozorňuje v obecné rovině Milan Damohorský In: DAMOHORSKÝ, M. Nové a nejnovější české stavební právo ve vztahu k ochraně životního prostředí. In: STAŠA, J. - RAJCHL, J. (eds.). Sondy do stavebního práva. Praha: Univerzita Karlova, Právnická fakulta, edice Sborníky 72, 2018, s. 152. 
uvádí důvodová zpráva a ani z důvodů, že stačí je nahradit procesem EIA, resp. že stačí jejich prosté vyjádření v rámci procesu EIA.

Záměry, resp. rozhodnutí podle stavebního zákona mohou být podle platné právní úpravy vydány až poté, co dojde $\mathrm{k}$ řádnému zhodnocení provedenému v souladu s požadavky směrnice 92/43/EHS (směrnice o stanovištích) a směrnice 2009/147/ES (směrnice o ptácích), tedy dle čl. 6 odst. 3a 4. směrnice o stanovištích (přes čl. 7 platí i pro ptáky), jejichž požadavky na naturové posouzení vlivů byly transponovány do § 45h a $\S 45$ i zákona č. 114/1992 Sb., o ochraně přírody a krajiny a nejsou tudíž totožné s obecnou úpravou v zákoně o posuzování vlivů na životní prostředí. Navrhovaná právní úprava ovšem mezi standardním a naturovým posuzováním vlivů (zatím) nerozlišuje!

\section{4. ÚVAHY NAD POSLANECKÝM NÁVRHEM ZÁKONNÉ ÚPRAVY PODPORUJÍCÍ VÝSTAVBU MALÝCH VODNÍCH NÁDRŽÍ}

Koncem loňského roku (1. listopadu 2018) se objevil poslanecký návrh č. 321/0, kterým se novelizuje stavební zákon a zákon o vodách, nová právní úprava se má týkat podpory výstavby malých vodních děl. ${ }^{7}$ Jistě jde o záměr bohulibého charakteru, zapadající do současných snah vládní koalice bojovat proti suchu a navracet vodu do krajiny. Ve skutečnosti se ovšem v návrhu skrývá další útok na věcnou působnost orgánů ochrany př́rody. V návrhu se objevuje jednak nesmyslná definice pojmu „malé vodní dílo“, když jím má být dle $§ 96$ stavebního zákona „výstavba vodních děl do plochy $20000 \mathrm{~m}^{2} \mathrm{~s}$ výškou hráze do 1,5 m, která slouží ke vzdouvání a akumulaci vod a která nepodléhají technickobezpečnostnímu dohledu nebo splňují kritéria pro zařazení do IV. kategorie technickobezpečnostního dohledu podle vodního zákona“. Taková představa velikosti je absurdní. Z pohledu cílů vodního zákona a rámcové směrnice o vodní politice není důvod, aby byla malá vodní díla zařazena do jednoduššího režimu územního souhlasu. Nádrže o velikosti do 2 ha již nelze považovat za jednoduché stavby. Návrh je také v rozporu s $§ 96$ odst. 1 stavebního zákona, kdy územní souhlas nelze vydat v př́padech záměrů, pro které je vyžadováno závazné stanovisko k posouzení vlivů provedení záměru na životní prostředí podle zákona o posuzování vlivů na životní prostředí. V prrípadě vodních nádrží či takto rozsáhlých terénních úprav může jít totiž o př́ípady posuzování vlivů na soustavu Natura 2000.

Problém ovšem spatřuji ve formulaci novely $§ 96$ odst. 3 stavebního zákona. V něm se na konci textu písmene b) doplňují slova: „nejde-li o záměr umistovaný v území chráněném podle části třetí nebo čtvrté zákona o ochraně přirody a krajiny, nevyžaduje se závazné stanovisko orgánu ochrany prírody, pokud jde o terénni úpravy podle odstavce 2 písm. h) nebo vodni díla podle odstavce 2 písm. i)“. Podobně se navrhuje text v novel $\S 15$ a odst. 4 vodního zákona. K ohlášení stavby, resp. k vydání územního souhlasu by

7 Návrh poslanců Jana Birke, Pavla Kováčika, Karla Turečka a Zdeňka Podala na vydání zákona, kterým se mění zákon č. 183/2006 Sb., o územním plánování a stavebním řádu (stavební zákon), ve znění pozdějších předpisů, a zákon č. 254/2001 Sb., o vodách a o změně některých zákonů (vodní zákon), ve znění pozdějších předpisů. 
tedy nebyly zapotřebí závazná stanoviska orgánů ochrany přírody. S tím nelze souhlasit, a to $\mathrm{z}$ následujících důvodů.

Na str. 6 důvodové zprávy předkladatel uvádí, že výjimka z jednoduššího režimu se navrhuje pouze u záměrů umist’ovaných ve zvláště chráněných územích nebo územích chráněných v systému soustavy Natura $2000 .{ }^{8}$ Tady by ale mohlo dojít ke kolizi s legislativou EU i judikaturou SDEU, nebot' vlivy záměrů na území soustavy Natura 2000 se musí posuzovat i tehdy, pokud leží vně těchto území. Tím pádem není splněn ani režim § 96 odst. 1 stavebního zákona, kdy územní souhlas nelze vydat v př́ípadech záměrů, pro které je vyžadováno závazné stanovisko k posouzení vlivů provedení záměru na životní prostředí podle zákona o posuzování vlivů na životní prostředí.

Ani z textu návrhu novely zákona, ani z důvodové zprávy nevyplývá, co má předkladatel na mysli slovy „... nevyžaduje se závazné stanovisko orgánu ochrany př́ro$d y . .$. “. Z tohoto režimu vyjímá pouze část III. a IV. zákona č. 114/1992 Sb., ale i tak tato formulace není jasná. Upozorňuji, že v ostatních částech zákona č. 114/1992 Sb. není upraven žádný institut vyjadřování se orgánu ochrany přírody formou závazného stanoviska (ani jinou), pokud jde o terénní úpravy nebo vodní díla ve smyslu pozitivního působení na krajinu, biodiverzitu, fungování přírodních ekosystémů, zdraví člověka, včetně významných ekologicko-stabilizačních prvků v běžné kulturní krajině, ani k aktivitám k podpoře na vodu vázaných ekosystémů. Proto je nesmysl, jak tvrdí předkladatelé v důvodové zprávě, 2. Zvláštní část k bodu 2 (str. 8 dole), že ,je možné tento administrativní krok jako nadbytečný ušetřit a napomoci tak snazší realizaci uvedených záměrư “. ${ }^{9}$ Mé stanovisko je takové, že žádný takový nadbytečný administrativní krok totiž v zákoně č. 114/1992 Sb., o ochraně př́rody a krajiny neexistuje. Navrhovaná formulace úpravy $\S 96$ stavebního zákona by měla být vypuštěna. Jedná se o jediné logické řešení. Pokud by totiž měl předkladatel, jak se lze domnívat, na mysli vyblokovat použití např. části druhé zákona o ochraně přírody a krajiny, např. závazné stanoviska podle $\S 4$ odst. 2 nebo $\S 12$ odst. 2 zákona č. 114/1992 Sb., popřel by tak své argumenty v důvodové zprávě na str. 5, 6, 8-10, tj. že se má jednat o terénní úpravy a vodní díla „ve prospěch ochrany přirody a krajiny“. Uvedená řízení podle $\S 4$ odst. 2 nebo $\S 12$ odst. 2 se totiž týkají negativních zásahů, nikoliv pozitivních, a tudíž jejich vyloučení $\mathrm{z}$ řízení by zákonodárce vzhledem $\mathrm{k}$ cílům vodního zákona a zákona o ochraně př́rody a krajiny jistě nechtěl. ${ }^{10}$

\section{5. ÚVAHY NAD VĚCNÝM ZÁMĚREM REKODIFIKACE VEŘEJNÉHO STAVEBNÍHO PRÁVA}

Jak známo, v loňském roce uzavřelo Ministerstvo pro místní rozvoj (MMR) jménem České republiky s Hospodářskou komorou ČR dohodu o tom, že Hospodářská komora ČR připraví návrh nového stavebního zákona. V únoru 2019 Hospodářská

\footnotetext{
8 Viz důvodová zpráva http://www.psp.cz/sqw/text/tiskt.sqw?O=8\&CT=321\&CT1=0\#prilohy.

9 Tamtéž.

10 Za zmínku snad stojí, že vláda zaujala nesouhlasné stanovisko, mj. z důvodu reakcí na požadavky subjektů hospodařících v zemědělské krajině a lesích.
} 
komora ČR návrh věcného záměru nového stavebního zákona předložila MMR s tím, aby k němu ostatní ministerstva, jiné správní úřady, jakož i další instituce (napríklad veřejná ochránkyně práv ${ }^{11}$ ) a i nevládní profesní a jiné subjekty mohly uplatnit připomínky. ${ }^{12}$ Připomínek vesměs velmi kritických se sešlo na $1600 .{ }^{13}$ Rád bych na tomto místě shrnul některé zásadní úvahy a kritické výhrady $\mathrm{k}$ věcnému záměru rekodifikace veřejného stavebního práva.

Pokud jde o obsah stavebního zákona, ten upravuje ve své podstatě konfliktní vztahy, v nichž na jedné straně stojí stavebník, který chce rychle realizovat svoji stavbu, a na druhé straně vlastníci a uživatelé sousedních nemovitostí, obyvatelé, obce, ale i různé dotčené orgány a instituce, přičemž každý z nich hájí své zájmy, které jsou často v rozporu se zájmy stavebníka. Hospodářská komora ČR je zájmovým podnikatelským svazem, který sdružuje mimo jiné největší tuzemské stavební a developerské korporace. ${ }^{14}$ Reprezentuje tak v rámci vztahů upravených stavebním zákonem logicky zájmy jedné strany, a to podnikatele ve stavebnictví, potažmo stavebníky. Věcný záměr rekodifikace stavebního práva včetně návrhu nového stavebního zákona je však jednostranně a účelově zaměřený. Dle mého názoru jeho koncepce není z pohledu hájení veřejných zájmů, především na ochraně životního prostředí a lidského zdraví.

Není účelem tohoto př́ispěvku detailně rozebírat jednotlivá ustanovení věcného návrhu rekodifikace stavebního zákona. Rád bych ovšem upozornil na vybrané problémy z hlediska tématu tohoto př́spěvku. Věcný záměr nového stavebního zákona navrhuje, aby celé řadě dotčených správních orgánů (zejména orgánům ochrany př́rody a památkové péče) byla odňata část jejich působnosti související s výstavbou a byla převedena na stavební úřady. Má tak vzniknout model, ve kterém působnost týkající se ochrany celé řady zvláštních veřejných zájmů bude organizačně rozštěpena mezi (i) dosavadní správní orgány a (ii) stavební úřady, přičemž stavební úřady mají hájit tyto zvláštní veřejné zájmy v souvislosti s výstavbou, zatímco dosavadní správní orgány mají hájit ty samé zvláštní veřejné zájmy ve všech ostatních případech. Tento schizofrenní model je z hlediska organizačních principů státní správy nesmyslný a hrozí chaosem v řádné ochraně veřejných zájmů na úseku životního prostředí a památkové péče.

Věcný záměr nového stavebního zákona dále navrhuje, aby byla zásadním způsobem oslabena pravomoc těch dotčených správních orgánů, kterým má být ponechána jejich dosavadní působnost v ochraně životního prostředí, související s výstavbou, zejména

11 Podstatu problémů věcného záměru nového stavebního zákona shrnula veřejná ochránkyně práv ve svém článku ŠABATOVÁ, A. Záminka pro omezování práv. Lidové noviny, 6. 3. 2019.

12 Např́klad: Komise pro životní prostředí Akademie věd České republiky. Stanovisko k př́pravě nového stavebního zákona [online], 20.3.2019. Dostupné na: http://www.avcr.cz/opencms/export/sites/avcr.cz/.content /galerie-souboru/komise-pro-zivotni-prostredi/Akademie_ved_Stanovisko-KZP-k-priprave-noveho -stavebniho-zakona.doc; International council on monuments and sites (ICOMOS). Otevřený dopis ze dne 19. 2. 2019 [online]. Dostupné na: http://www.icomos.cz/images/prohlaseni/2019/prohlaseni-cnkicomos -rekodifikace.pdf; SVOBODA, P. a kol. Otevřený dopis vládě proti novému stavebnímu zákonu. Ekolist.cz [online], 23. 4. 2019. Dostupné na: https://ekolist.cz/cz/publicistika/nazory-a-komentare/petr-svoboda -a-kol.otevreny-dopis-vlade-proti-novemu-stavebnimu-zakona [vše cit. 1. 6. 2019].

13 Kritikou věcného záměru rekodifikace veřejného stavebního práva se zabývala i konference Sondy do stavebního práva, která se uskutečnila na Právnické fakultě UK v Praze v listopadu 2018. Viz STAŠA, J. - RAJCHL, J. (eds.). Sondy do stavebního práva. Praha: Univerzita Karlova, Právnická fakulta, edice Sborníky 72, 2018.

14 Viz zákon č. 301/1992 Sb., o Hospodářské komoře České republiky a Agrární komoře České republiky. 
jde o orgány ochrany př́rody podle zákona č. 114/1992 Sb., konkrétně správ národních parků a Agentury ochrany prrírody a krajiny ČR. Jejich pravomoc vydávat v řízení podle stavebního zákona $\mathrm{k}$ projednávaným stavebním záměrům závazná stanoviska má být změněna na pravomoc vydávat jen nezávazná vyjádření. Těmi by stavební úrad nebyl vázán a mohl by rozhodnout i v rozporu s nimi. Názor dotčených správních orgánů a ochrana jimi hájených veřejných zájmů by tak měla být v řízení podle stavebního zákona procesně degradována a stavební úrad by mohl autoritativně zasahovat do výkonu jejich působnosti, a to např́íklad i na území národních parků. To je absolutně nepřijatelné. K takovým krokům, resp. takové zásadní změně není žádný věcný ani právní, žádný rozumný ani logický důvod. Představuje extrémní riziko pro ochranu zákonnosti a veřejných zájmů na ochranu př́rody a krajiny. Dle mého názoru by se také taková právní úprava dostala do rozporu s čl. 7 Ústavy ČR. Podle tohoto ustanovení „stát dbá na šetrné využivání přirodních zdrojů a ochranu přirodního bohatstvi". Podle judikatury Ústavního soudu zde stát hájí veřejný zájem na ochraně životního prostředí. ${ }^{15}$ Obsah věcného záměru rekodifikace veřejného stavebního práva však svědčí o pravém opaku.

Podle stanoviska Legislativní rady vlády ${ }^{16}$, ,z návrhu věcného záměru není úplně jasné, jaký okruh dotčených orgánů má zůstat zachován, aniž by jejich dosavadní kompetence přšlly na novou stavební správu, nebot'v př́padě, kdy má dojit ke změně formy závazných stanovisek dotčených orgánů na formu vyjádření, je v návrhu pouze demonstrativní výčet orgánů, které, resp. jejich kompetence, maji zůstat zachovány jako SÚJB ${ }^{17}$ nebo správy národních parků.“”

$\mathrm{Z}$ návrhu není dále jasné ani to, jak to bude např́iklad s postavením Ministerstva životního prostředí jakožto ústředního správního úř̌adu, do jehož působnosti podle zákona č. 2/1969 Sb., kompetenčního zákona, v současné době patř́ oblast státní správy vykonávané dotčenými orgány, pakliže jejich působnost přejde na nově vytvořené orgány státní stavební správy. Legislativní rada vlády se doslova ptá, ,jaký bude (zejména z hlediska kompetenčního zákona) vztah mezi působností těchto ministerstev a Nejvyššim stavebním úr̆adem". ${ }^{18}$

Z návrhu nevyplývá ani to, jak daleko předpokládaná integrace půjde $\mathrm{v}$ případě takových souvisejících správních agend, jako jsou např. kompenzační opatření podle $\S 45 i$ zákona č. 114/1992 Sb., pokud jde o předpokládanou integraci kompetencí orgánů ochrany prrírody a krajiny. Toto souvisí s procesem tzv. naturového posuzování vlivů, který vyžaduje čl. 6 odst. 3 a 4 směrnice o stanovištích.

Za závažné považuji i to, že ve věcném záměru nového stavebního zákona nejsou konkrétně identifikována př́slušná kompetenční ustanovení složkových předpisů, která mají být integrována či jinak změněna. Dle stanoviska legislativní rady vlády „návrh zmiňuje pouze předchozi predběžné prověreni těchto ustanovení. Navrhované řěsení nesvědči o př́liš koncepčním a promyšleném př́stupu k zajištěni ochrany dotčených

15 Viz např. sp. zn. IV.ÚS 254/02 ze dne 28. 1. 2003 nebo nález ÚS ze dne 13. 12. 2006 sp. zn. 34/03 nebo další nálezy: sp. zn. 256/2010 ze dne 8. 7. 2010 nebo nález sp. zn. P1. ÚS 18/17 ze dne 25. 9. 2018.

16 Stanovisko pracovní komise legislativní rady vlády pro návrh věcného záměru stavebního zákona ze dne 27. května 2019 čj. 393/19.

17 Míněn Státní úřad pro jadernou bezpečnost.

18 Stanovisko pracovní komise legislativní rady vlády pro návrh věcného záměru stavebního zákona ze dne 27. května 2019 čj. 393/19. 
veřejných zájmů. Např. povolování nakládání s vodami zůstává v působnosti vodoprávnich úradư, pokud ovšem neni nahrazeno integrovaným povolením, které je, svým rozsahem výrazně presahujicím problematiku nakládánís vodami (o povolováni staveb nemluvě), integrováno do povolení stavby. Působnost orgánů památkové péče integrována v prípadě nemovitých kulturních památek, památkových rezervací či zón (zcela správně) není, působnost orgánů ochrany prírody (AOPK, správy NP) je redukována na pouhá vyjádření i v prípadech dotčení mimořádně cenných a jedinečných území, jako jsou zejména národní př́rodní rezervace, národní přirodní památky či národního par$k u$. "19 Zcela s tímto názorem souhlasím. Proč orgány památkové péče mají jiný režim než speciální orgány ochrany př́rody? Oba dva typy orgánů mají hájit veřejný zájem. $\mathrm{Z}$ návrhu věcného záměru toto dle mého názoru patrné není.

Věcný záměr nového stavebního zákona dále navrhuje model, v rámci kterého by počítačový systém ,automaticky vygeneroval“ stavebníkovi rozhodnutí o povolení stavby, pokud by stavební úřad nestihl ve stanovené lhůtě vydat rozhodnutí. Tento model umožňuje, aby bylo legálně vydáno povolení stavby i v rozporu se zákonem, s územním plánem, bez ohledu na námitky dalších účastníků řízení i stanoviska dotčených správních orgánů. Představuje extrémní riziko pro ochranu zákonnosti, veřejných zájmů i soukromých práv a zájmů dalších účastníků řízení a je patrně i v rozporu s obecnými zásadami správního práva. ${ }^{20}$

\section{ZÁVĚRY}

Domnívám se, že ani $\mathrm{k}$ jedné změně z výše uvedených nebyl racionální důvod, že všechny představují pouze politické rozhodnutí, jdoucí na ruku stavebníkům a developerům a které je třeba odmítnout, resp. v prípadě již provedených změn usilovat o jejich vypuštění ze zákonného textu při př́ípadné novelizaci zákona č. 114/1992 Sb.

Konstrukce $\S 8$ odst. 6 zákona č. 114/1992 Sb. je zbytečným ústupkem státní ochrany přírody vůči požadavkům stavebníků. Jak jsem však poukázal výše, část odborné veřejnosti je k této změně otevřená. Konstrukce $\$ 56$ odst. 6 zákona č. 114/1992 Sb. je dle mého názoru nejasná, nelogická, nesystémová a problematická, kritizovaná odbornou literaturou.

Návrh $\S 2$ odst. 8 zákona č. 416/2009 Sb. z jara 2019 je věcně i právně chybný, nedůvodný a nesystémový. $K$ tomuto návrhu však zatím odborná literatura neexistuje. Je tř̌eba uhájit pravomoci orgánů ochrany př́rody vydávat samostatná rozhodnutí v rámci řetězení správních aktů, podmiňující výsledek řízení o povolování stavebních záměrů a tam, kde podle stávající právní úpravy mají oprávnění vydávat „,jen“ závazná stanoviska do různých řízení podle stavebního zákona, tyto pravomoci zachovat.

K návrhu novely zákonů o urychlení výstavby malých vodních děl v krajině opět třeba upozornit, že se jedná o účelové řešení, mající za cíl zamezit orgánům ochrany

19 Tamtéž.

20 Touto problematikou se zabýval především Petr Svoboda in SVOBODA, P. Jak nepřestavět české stavební právo. Česká pozice, ceskapozice.lidovky.cz, 2019. Další kritické poznámky viz např. STUDNIČKA, M. Nový stavební zákon aneb rychlost nade vše? Právní rozhledy, 2019, č. 9, s. 331-333. 
prrírody hájit veřejný zájem na ochraně prírody. Výstavbou „malých“ vodních děl o velikosti 2 ha by došlo, v prrípadě, že by byla schválena navrhovaná právní úprava, k řadě ztrát přirozených mokřadních území v krajině.

Výše uvedené problémy se týkají samozřejmě také postavení orgánů ochrany prírody $\mathrm{v}$ rámci věcného záměru nového stavebního zákona. Dle mého názoru je de lege feren$d a$ třeba věcný záměr v těch částech, které se dotýkají změn v postavení a působnosti orgánů ochrany prírody odmítnout. Je třeba zdůraznit nutnost zachování věcné a místní působnosti orgánů ochrany přírody ve věcech hájení veřejného zájmu na ochraně přírody a prosazování cílů ochrany prírody $\mathrm{v}$ rízeních $\mathrm{v}$ rámci forem správních činností, především ve věcech vydávání rozhodnutí, souhlasů, závazných stanovisek a opatření obecné povahy podle zákona č. 114/1992 Sb., o ochraně př́rody a krajiny, a to i ve vztahu k ř́zením podle stavebního zákona. Je nezbytně nutné zachovat jejich postavení dotčených orgánů státní správy, ve smyslu § 136 odst. 1 písm. b) správního řádu.

Dle mého názoru by se také taková právní úprava dostala do rozporu s čl. 7 Ústavy ČR. Podle tohoto ustanovení „stát dbá na šetrné využivání přirodních zdrojů a ochranu prírodniho bohatstvi". Podle výše uvedené judikatury Ústavního soudu zde stát hájí veřejný zájem na ochraně životního prostředí. Obsah věcného záměru rekodifikace veřejného stavebního práva však svědčí o pravém opaku.

doc. JUDr. Vojtěch Stejskal, Ph.D.

Právnická fakulta Univerzity Karlovy

stejskal@prf.cuni.cz

ORCID: 0000-0002-8783-7190 